\title{
Increased Frequency of Micronuclei in Binucleated Lymphocytes among Occupationally Pesticide-exposed Populations: A Meta- analysis
}

\author{
Hai-Yan Yang ${ }^{1 \&}$, Ruo Feng ${ }^{2 \&}$, Jing Liu ${ }^{1}$, Hai-Yu Wang ${ }^{3}$, Ya-Dong Wang*
}

\begin{abstract}
Background: The cytokinesis-block micronucleus (CBMN) assay is a standard cytogenetic tool employed to evaluate chromosomal damage subsequent to pesticide exposure. Objectives: To evaluate the pooled levels of total micronuclei (MN) and binucleated cells with micronuclei $(\mathrm{MNC})$ in 1000 binucleated lymphocytes among population occupationally exposed to pesticides and further determine the more sensitive biomarker of CBMN. Materials and Methods: A meta-analysis on the pooled levels of MN and MNC in binucleated lymphocytes among occupationally pesticide-exposed populations was conducted using STATA 10.0 software and Review Manager 5.0.24 in this study. Results: We found significant differences in frequencies of $M N$ and MNC in 1000 binucleated lymphocytes between pesticide-exposed groups and controls, and the summary estimates of weighted mean difference were 6.82 [95\% confidence interval $(95 \% \mathrm{CI}): 4.86-8.78]$ and 5.08 (95\% CI: 2.93-7.23), respectively. However, when we conducted sensitivity analyses further, only the MN remained statistically different, but not the MNC, the summary estimates of weight mean difference were 2.86 (95\% CI: $2.51-3.21$ ) and 0.50 (95\% CI: -0.16-1.17), respectively. We also observed pesticide-exposed subjects had significantly higher MN frequencies than controls among smokers and nonsmokers, male and female populations, and American, Asian and European countries in stratified analyses. Conclusions: The frequency of MN in peripheral blood lymphocytes might be a more sensitive indicator of early genetic effects than MNC using the CBMN assay for occupationally pesticideexposed populations.
\end{abstract}

Keywords: Cytokinesis-block micronucleus - pesticides - peripheral blood lymphocytes - meta-analysis

Asian Pac J Cancer Prev, 15 (16), 6955-6960

\section{Introduction}

Pesticides are a group of natural or synthetic chemical substances, being designated to fight against plagues that generally attack, harm or transmit illness to living organisms including humans. Since they are extensively used throughout the world, large amounts of pesticides are set free into the environment annually. It is reported that many of them have adverse biological effects on non-target organisms including humans. Therefore, concerns for their potential hazard to human health have been increasing. Human exposure to pesticides can occur via dermal contact, inhalation, ingestion, or across the placenta (Gilden et al., 2010). Individuals occupationally exposed to pesticides included farm workers, floriculturists, pesticides applicators and pesticides manufacturing workers, etc (Alavanja, 2009). Most pesticides are of acute and chronic toxicity to humans.

Chronic health effects have been related to environmental exposure to pesticides, including neurological effects, reproductive or developmental dysfunctions and certain cancer. Epidemiological studies have shown that there was an etiologic link between occupational exposure to pesticides and several human neoplastic diseases. In particular, a significant increase was observed in the incidence of multiple myeloma (Rusiecki et al., 2009), Hodgkin's lymphoma (Orsi et al., 2009), non-Hodgkin's lymphoma (Fritschi et al., 2005; Merhi et al., 2007; Balasubramaniam et al., 2013; Yildirim et al., 2013), soft tissue sarcoma (Hardell et al., 1995), and lung (Lee et al., 2004), pancreas (Andreotti et al., 2009), liver (Weichenthal et al., 2010), colon and rectum (Lee et al., 2007), leukemia (Van Maele-Fabry et al., 2007; Rajabli et al., 2013; Kumar et al., 2014), prostate (Alavanja et al., 2003; Van Maele-Fabry et al., 2006) and bladder cancer (Koutros et al., 2009).

Human biomonitoring is a useful tool of great interest in cancer risk assessment once it allows estimating genetic risks deriving from environmental exposure to chemicals (Costa et al., 2006). The genotoxic effects of pesticides are

${ }^{1}$ Department of Epidemiology, School of Public Health, Zhengzhou University, ${ }^{2}$ Department of Histology and Embryology, School of Basic Medicine, Zhengzhou University, ${ }^{3}$ Department of Toxicology, Henan Center for Disease Control and Prevention, Zhengzhou, China ${ }^{\circledR}$ Equal contributors *For correspondence: wangyd76@163.com 
primary factors for carcinogenesis, and thus, cytogenetic biomonitoring will become useful in human population occupationally exposed to pesticides. Recently, many biomonitoring studies have investigated biomarkers of cytogenetic damage including chromosomal aberrations (CA), sister chromatids exchange (SCE) and cytokinesisblock micronucleus (CBMN) among pesticide-exposed population. Among them, $\mathrm{CBMN}$ in human peripheral blood lymphocytes is one of the most extensively studied biomarkers of cytogenetic damage (Bolognesi et al., 2011). However, a single study with relatively small sample may not be sufficient to present a robust evidence of the relationship between pesticides exposure and increased frequencies of CBMN in human peripheral blood lymphocytes. Moreover, various types of study populations and study designs may also have contributed to diversify the findings. Meta-analysis represents the ideal statistical tools for calculating pooled estimates of a biomarker using data from different studies, which seems to be one of the most informative ways to extract information from different studies on biomarkers when the evidence from single study is too sparse to provide definite conclusions (Taioli et al., 2002). Therefore, we collected the published data to evaluate the validation of CBMN in human peripheral blood lymphocytes as cytogenetic biomarkers of occupationally pesticideexposed population comprehensively.

\section{Materials and Methods}

\section{Literature source and analytical methods}

We searched the databases of Medline/PubMed, EMBASE and web of science, using the combinations of the following key words: "micronucleus", "pesticide", "insecticide", "fungicide", "herbicide", "farmer", "floriculturist" and "lymphocyte", the ending date of searched publications was December 31, 2013. A cited reference search of the retrieved papers was conducted, and further publications were also identified by retrieving the bibliographies of the retrieved papers.

Criteria of literature inclusion: (1) The papers should be published in English; (2) The genetic damage was assessed by CBMN assay in human peripheral blood lymphocytes; (3) The papers should include occupational exposure to pesticides and the frequency of $\mathrm{MN}$ or MNC in peripheral blood lymphocytes; (4) The paper must offer the exposed group and control group; (5) The paper must offer the size of the sample, arithmetic means and standard deviations (SD) or the information that can help infer the results; (5) When more than one article was identified for the same study population, we included the most recent population or publication including more information. Accordingly, reviews and repeated or overlapping literatures were excluded.

In total, 36 published studies were identified with the frequencies of CBMN in peripheral blood lymphocytes of occupationally pesticide-exposed population. We reviewed all papers in accordance with the criteria defined above and excluded ten overlapping articles, one review and two papers that did not offer full information. Therefore, twenty-three studies were determined to enter our study. Among them, twenty-two studies focused on $\mathrm{MN}$ and twelve studies focused on MNC.

\section{Data extraction}

Two data managers tabulated the data first, and then inputted them to an electronic database, independently. The following information was extracted from the studies: authors, publishing year, arithmetic means and standard deviations, sample size of exposed group and control group, origin of country, study design, statistical test, duration and stratified factors.

We calculated the summary arithmetic means and standard deviations, if the study provided stratum information. Several characteristics of individual study were summarized in Table 1.

\section{Quantitative data synthesis}

To evaluate the association between CBMN frequency and occupational exposure to pesticides, we performed a meta-analysis of identified studies. Data were combined using either a fixed-effects model or a random-effects model (DerSimonian et al., 1986). The Cochrane Q statistics test was carried out for the assessment of heterogeneity. A fixed-effects model is employed when the effects are assumed to be homogenous, while a randomeffects model is employed when they are heterogeneous. We computed the weighted mean difference and 95\% confidence interval (95\% CI) for each study. Publication bias was concerned in this meta-analysis. The presence of publication bias signified that non-significant or negative finding remained unpublished. The funnel plot was drawn to evaluate publication bias and Egger's test was used to test the funnel plot symmetry (DerSimonian et al., 1986; Egger et al., 1997). Begg's rank correlation test was employed to check the publication bias as well (Begg et al., 1994).

All of the statistical analyses were conducted with STATA 10.0 software package (Stata Corporation, College Station, Texas) and Review Manager (Version 5.0.24, The Cochrane Collaboration). All the tests were two-sided, and a $\mathrm{P}$ value of less than 0.05 for any test or model was considered to be statistically significant.

\section{Results}

Meta-analysis databases

We established a database according to the extracted information from each article. General information of included studies was listed in Table 1. It indicates first author, year of publication, exposure of pesticides, duration, outcome measure, origin of country, study design, covariate accounted for and statistical test. There were a total of 22 studies with 1278 exposed individuals and 1026 controls concerning MN frequency (Figure 1A) and 12 studies with 880 exposed individuals and 560 controls concerning MNC frequency (Figure 1B).

\section{Test of heterogeneity}

Table 2 shows the association between CBMN frequency and exposure to pesticides. The heterogeneity of studies on MN and MNC was analyzed for the 23 studies. 
The results showed that there was not heterogeneity for meta-analysis on $\mathrm{MN}$ in female population. Thus, we computed the summary estimate of weighted mean difference for it with a fixed-effects model. The rest had heterogeneity with $\mathrm{P}$ value being less than 0.05 . Therefore, we analyzed the summary estimates of weighted mean difference for them with a random-effects model.

\section{Quantitative data synthesis}

Table 2 indicates the summary estimates of weighted mean difference of the frequencies of $\mathrm{MN}$ and $\mathrm{MNC}$, There were statistically significant differences in the frequencies of $\mathrm{MN}$ and $\mathrm{MNC}$ in peripheral blood lymphocytes between pesticide-exposed group and control, and the summary estimates of weighted mean difference were $6.82(95 \%$

Table 1. General Information of the Studies Included in this Meta-analysis

\begin{tabular}{|c|c|c|c|c|c|c|c|c|}
\hline Author & Year & Exposure to pesticide & $\begin{array}{l}\text { Outcome } \\
\text { measure }\end{array}$ & $\begin{array}{c}\text { Duration } \\
(\text { Mean } \pm \text { SD })\end{array}$ & Country & Study design & $\begin{array}{l}\text { Covariates } \\
\text { accounted for }\end{array}$ & Statistical test \\
\hline Ali et al & 2008 & $\begin{array}{l}\text { Carbamate, pyrethroid, and } \\
\text { Organophosphate }\end{array}$ & $\begin{array}{c}\mathrm{MN} \\
\text { and MNC }\end{array}$ & $\begin{array}{c}10.26 \pm 6.14 \\
\text { years }\end{array}$ & Pakistan & Retrospective & Age and duration & Mann-Whitney U tests \\
\hline Bhalli et al & 2006 & $\begin{array}{l}\text { Complex mixtures } \\
\text { of pesticides }\end{array}$ & $\begin{array}{c}\mathrm{MN} \\
\text { and } \mathrm{MNC}\end{array}$ & $\begin{array}{c}13.48 \pm 3.84 \\
\text { years }\end{array}$ & Pakistan & Retrospective & Smoking and duration & Mann-Whitney U test \\
\hline Bolognesi et al & 1993 & $\begin{array}{l}\text { Complex mixture } \\
\text { of compounds }\end{array}$ & $\mathrm{MN}$ & $\begin{array}{c}25.3 \pm 13.23 \\
\text { years }\end{array}$ & Italy & Retrospective & $\begin{array}{l}\text { Age, sex, smoking } \\
\text { and duration }\end{array}$ & $\begin{array}{l}\text { Poisson regression } \\
\text { analysis }\end{array}$ \\
\hline Bolognesi et al & 2004 & $\begin{array}{l}\text { Complex mixture } \\
\text { of pesticides }\end{array}$ & MNC & $\begin{array}{l}26.35 \pm 14.46 \\
\text { years }\end{array}$ & Italy & Retrospective & Sex, age and smoking & Mann-Whitney U test \\
\hline Bolognesi et al & 2009 & $\begin{array}{l}\text { Glyphosate and } \\
\text { other pesticides }\end{array}$ & $\begin{array}{c}\text { MN } \\
\text { and MNC }\end{array}$ & Unknown & Colombia & Prospective & Region, sex and age & One-way ANOVA \\
\hline Coskun et al & 2011 & Mixing of pesticides & $\begin{array}{c}\mathrm{MN} \\
\text { and MNC }\end{array}$ & Unknown & Turkey & Retrospective & Age and sex & Student's t-test \\
\hline Costa et al & 2006 & $\begin{array}{l}\text { Insecticides, Rodenticide, } \\
\text { Acaricides and Herbicides }\end{array}$ & $\mathrm{MN}$ & $\begin{array}{l}15 \pm 13 \\
\text { years }\end{array}$ & Portugal & Retrospective & Sex and smoking & Analysis of variance \\
\hline Costa et al & 2011 & $\begin{array}{l}\text { Fungicides, Insecticides, } \\
\text { Herbicides and Aphicides }\end{array}$ & MN & $\begin{array}{c}23.0 \pm 16.1 \\
\text { years }\end{array}$ & Portugal & Retrospective & Sex and smoking & Mann-Whitney tests \\
\hline Davies et al & 1998 & Farmworkers & $\begin{array}{c}\mathrm{MN} \\
\text { and MNC }\end{array}$ & $\begin{array}{l}7.33 \text { years } \\
\text { (range: } 1-24)\end{array}$ & British & Retrospective & $\begin{array}{l}\text { Duration, age, folate, } \\
\text { meat, coffee and } \\
\text { recent vaccination }\end{array}$ & $\begin{array}{l}\text { ANOVA and Student's } \\
\text { t-test }\end{array}$ \\
\hline Figgs et al & 2000 & $\begin{array}{l}\text { 2, 4-dichloropheno- } \\
\text { xyacetic acid }\end{array}$ & $\mathrm{MN}$ & Unknown & USA & Prospective & Unknown & t-test \\
\hline Garaj-Vrhovac et al & 2002 & $\begin{array}{l}\text { Atrazine, alachlor, cyanazine, } \\
\text { 2, 4-dichlorophenoxyacetic- } \\
\text { acid and malathion }\end{array}$ & MN & $\begin{array}{l}22.25 \text { years } \\
\text { (range: } 4-30)\end{array}$ & Croatia & Retrospective & Smoking & Chi-squared test \\
\hline Joksic et al & 1997 & Herbicide and Fungicide & $\mathrm{MN}$ & $\begin{array}{c}12.1 \pm 6.02 \\
\text { years }\end{array}$ & Yugoslavia & Prospective & Unknown & Wilcoxon rank-sum test \\
\hline Kehdy et al & 2007 & Several pesticides & $\begin{array}{c}\mathrm{MN} \\
\text { and MNC }\end{array}$ & $\begin{array}{c}5.28 \pm 3.23 \\
\text { years }\end{array}$ & Brazil & Retrospective & $\begin{array}{l}\text { Age, smoking, } \\
\text { drinking and } \\
\text { duration }\end{array}$ & Analysis of covariance \\
\hline Lucero et al & 2000 & $\begin{array}{l}\text { Complex mixture } \\
\text { of pesticides }\end{array}$ & $\begin{array}{c}\mathrm{MN} \\
\text { and } \mathrm{MNC}\end{array}$ & $\begin{array}{c}9.82 \pm 8.08 \\
\text { years }\end{array}$ & Spain & Retrospective & $\begin{array}{l}\text { Age, smoking and } \\
\text { duration }\end{array}$ & $\begin{array}{l}\text { One-way analysis of } \\
\text { covariance }\end{array}$ \\
\hline Marquez et al & 2005 & $\begin{array}{l}\text { Insecticides, Fungicide } \\
\text { and Herbicide }\end{array}$ & $\begin{array}{c}\mathrm{MN} \\
\text { and MNC }\end{array}$ & $\begin{array}{c}8.0 \pm 4.8 \\
\text { years }\end{array}$ & Chile & Retrospective & Smoking and duration & Mann-Whitney U test \\
\hline Pasquini et al & 1996 & $\begin{array}{l}\text { Insecticides, Herbicides } \\
\text { and Fungicides }\end{array}$ & $\mathrm{MN}$ & $\begin{array}{c}18.35 \pm 12.42 \\
\text { years }\end{array}$ & Italy & Retrospective & $\begin{array}{l}\text { Age, smoking and } \\
\text { duration }\end{array}$ & Variance analysis \\
\hline Pastor et al & 2003 & $\begin{array}{l}\text { Insecticides, Fungicides, } \\
\text { Herbicides and } \\
\text { Bactericides }\end{array}$ & $\begin{array}{c}\mathrm{MN} \\
\text { and MNC }\end{array}$ & $\begin{array}{l}13.92 \pm 9.11 \mathrm{G} \\
\text { years }\end{array}$ & $\begin{array}{l}\text { Sreece, Spain, } \\
\text { Poland and } \\
\text { Hungary }\end{array}$ & Retrospective & Sex & Generalized linear model \\
\hline Rohr et al & 2010 & Pesticides & $\mathrm{MN}$ & $\begin{array}{c}29.86 \pm 14.2 \\
\text { years }\end{array}$ & Brazil & Retrospective & Genotype & Mann-Whitney U test \\
\hline Scarpato et al & 1996 & $\begin{array}{l}\text { Greenhouse } \\
\text { floriculturists }\end{array}$ & MN & Unknown & Italy & Retrospective & Smoking and sex & $\begin{array}{l}\text { Multiple linear or Poisson } \\
\text { Regression analysis }\end{array}$ \\
\hline Titenko-Holland et al & 1997 & $\begin{array}{l}\text { Malathion } \\
\text { and MNC }\end{array}$ & $\begin{array}{l}\text { MN } \\
\text { e last } 6 \text { month }\end{array}$ & Exposure in & USA & Prospective & Sex & Chi-square test for trend \\
\hline Tope et al & 2006 & $\begin{array}{l}\text { Complex mixture of } \\
\text { pesticides }\end{array}$ & $\mathrm{MN}$ & $\begin{array}{c}18.2 \pm 5.03 \\
\text { years }\end{array}$ & USA & Retrospective & Unknown & One-way ANOVA \\
\hline Venegas et al & 1998 & $\begin{array}{l}\text { Mixtures of } \\
\text { pesticides }\end{array}$ & $\begin{array}{c}\mathrm{MN} \\
\text { and MNC }\end{array}$ & About 7 years & Chile & Retrospective & Age and drinking & t-test \\
\hline Zeljezic et al & 2007 & Carbofuran & $\mathrm{MN}$ & $\begin{array}{c}15.7 \text { years } \\
\text { (range: } 1-29) t\end{array}$ & Croatia & Retrospective & $\begin{array}{l}\text { Sex, age, smoking, } \\
\text { drinking and } \\
\text { X-ray exposure }\end{array}$ & Multivariate analysis \\
\hline
\end{tabular}

Table 2. Summary Results of Meta-analysis on Cytokinesis-block Micronuclei Induced by Pesticide Exposure

\begin{tabular}{|c|c|c|c|c|c|c|c|c|c|c|c|c|}
\hline \multirow[t]{2}{*}{ Biomarker } & \multirow{2}{*}{$\begin{array}{c}\text { Exposure } \\
\text { /control }\end{array}$} & \multicolumn{2}{|c|}{ Heterogeneity test } & \multirow[t]{2}{*}{ Analysis Model } & \multirow{2}{*}{$\begin{array}{l}\text { Summary estimate } \\
\text { of weighted mean } \\
\text { difference }(95 \% \mathrm{CI})\end{array}$} & \multicolumn{2}{|c|}{ Hypothesis test } & \multirow[t]{2}{*}{$d f$} & \multicolumn{2}{|c|}{ Egger's test } & \multicolumn{2}{|c|}{ Begg's test } \\
\hline & & $Q$ & $P$ & & & $Z$ & $P$ & & $t$ & $P$ & $Z$ & $P$ \\
\hline MN & $1278 / 1026$ & 695.2 & $<0.00001$ & Random-effects & $6.82(4.86-8.78)$ & 6.82 & $<0.00001$ & 21 & 1.93 & 0.068 & 1.80 & 0.071 \\
\hline \multicolumn{13}{|c|}{ Stratification by smoking } \\
\hline Smokers & $63 / 74$ & 100.43 & $<0.00001$ & Random-effects & $10.09(4.11-16.07)$ & 3.31 & 0.001 & 5 & 1.51 & 0.205 & 1.13 & 0.260 \\
\hline Nonsmokers & $208 / 222$ & 62.95 & $<0.00001$ & Random-effects & $6.65(3.32-9.98)$ & 3.91 & 0 & 5 & 1.74 & 0.156 & 0.75 & 0.452 \\
\hline \multicolumn{13}{|c|}{ Stratification by sex } \\
\hline Male & $199 / 178$ & 15.97 & 0.007 & Random-effects & $2.73(1.29-4.17)$ & 3.71 & 0 & 5 & 0.99 & 0.380 & 0.75 & 0.452 \\
\hline Female & $103 / 117$ & 7.77 & 0.169 & Fixed-effects & $4.76 \quad(2.94-6.57)$ & 5.14 & $<0.00001$ & 5 & 0.06 & 0.954 & 0.00 & 1.000 \\
\hline \multicolumn{13}{|c|}{ Stratification by origin of country } \\
\hline America & $488 / 229$ & 183.26 & $<0.00001$ & Random-effects & $5.89 \quad(2.86-8.92)$ & 3.8 & 0.0001 & 7 & 0.88 & 0.413 & 0.12 & 0.902 \\
\hline Asia & $114 / 152$ & 35.95 & $<0.00001$ & Random-effects & $8.82(4.80-12.85)$ & 4.29 & $<0.0001$ & 2 & 0.58 & 0.668 & 0.00 & 1.000 \\
\hline Europe & $646 / 645$ & 300.66 & $<0.00001$ & Random-effects & $7.28 \quad(4.03-10.54)$ & 4.38 & 0 & 10 & 2.19 & 0.057 & 1.56 & 0.119 \\
\hline $\mathrm{MNC}$ & $880 / 560$ & 332.55 & 0 & Random-effects & $5.08 \quad(2.93-7.23)$ & 4.63 & $<0.00001$ & 11 & 0.98 & 0.350 & 0.75 & 0.451 \\
\hline
\end{tabular}




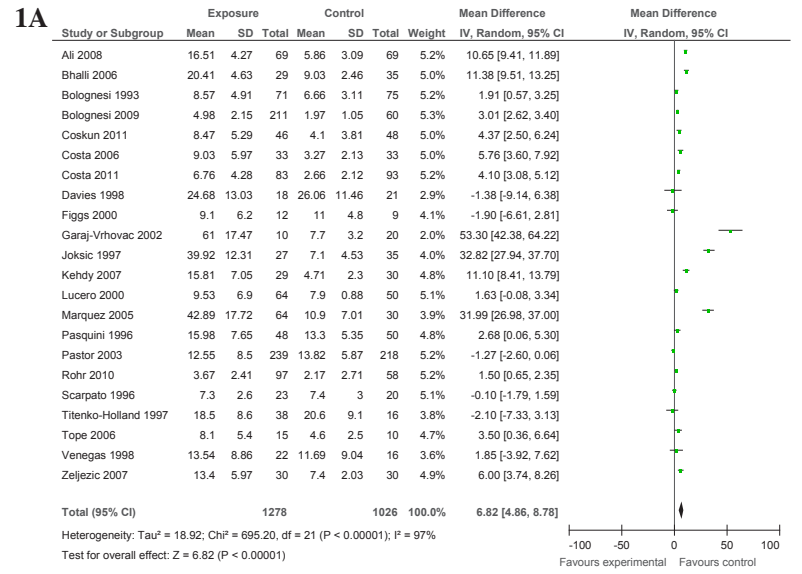

$1 \mathrm{~B}$

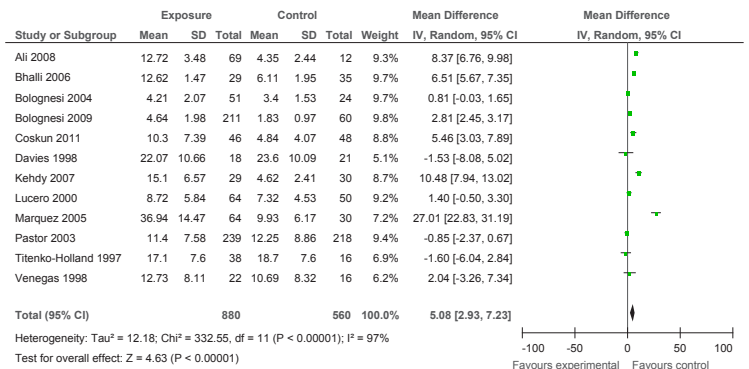

Figure 1. Meta-analysis of Total Micronuclei (MN) (1A) and Binucleated Cells with Micronuclei (MNC) (1B) in 1000 Binucleated Lymphocytes Among Total Population. Each estimate of weighted mean difference on $\mathrm{MN}$ and MNC was designated by a solid square, and the $95 \%$ confidence interval $(95 \% \mathrm{CI})$ of each subgroup was shown by transverse line. The blank rhombus at the bottom was the pooled estimate of weighted mean difference by random-effects model
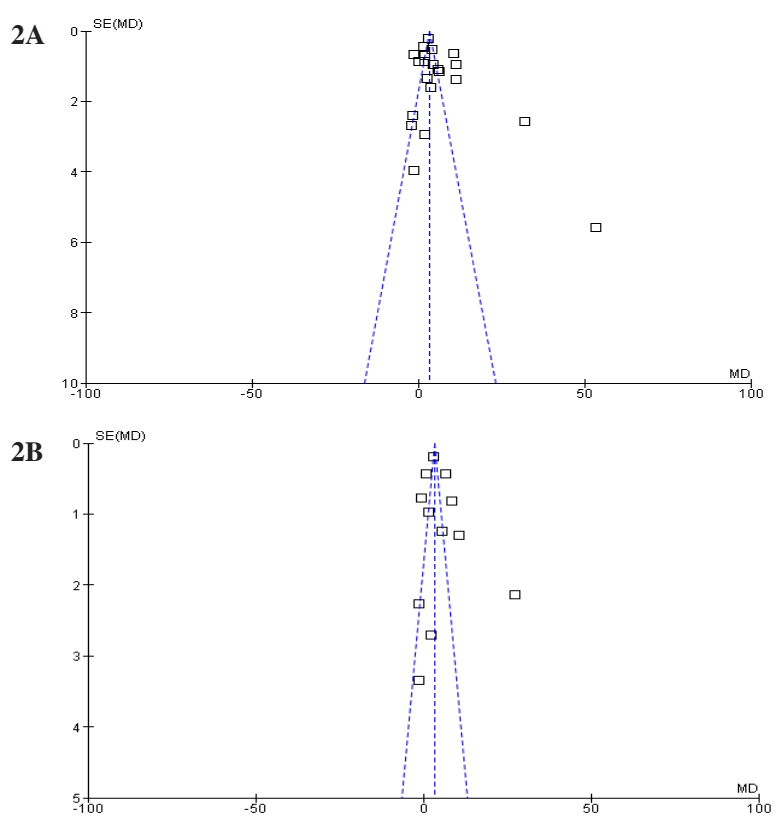

Figure 2. Funnel Plot Analyses to Detect Publication Bias for MN (2A) and MNC (2B)

CI: 4.86-8.78) (Figure 1A) and 5.08 (95\% CI: 2.93-7.23) (Figure 1B), respectively. We performed meta-analysis on $\mathrm{MN}$ frequency stratified by cigarette smoking, sex and origin of country further, our findings showed that there were statistically significant differences in the frequency of $\mathrm{MN}$ in peripheral blood lymphocytes between pesticide-
3A

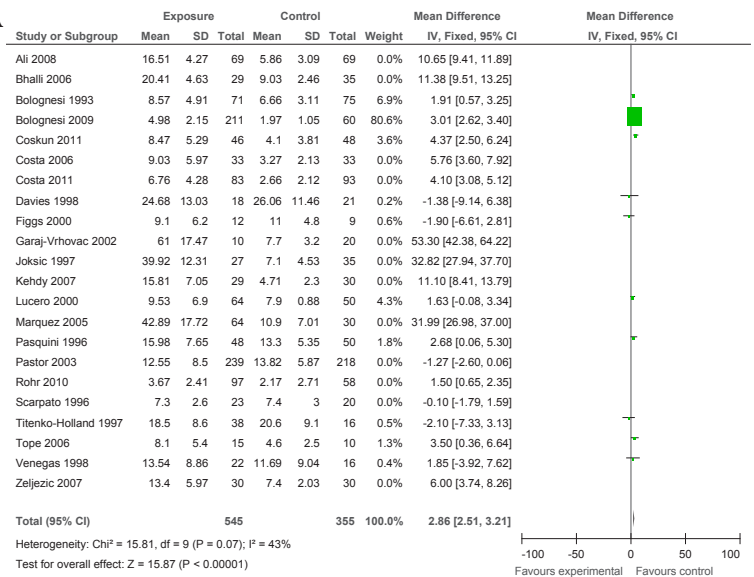

3A

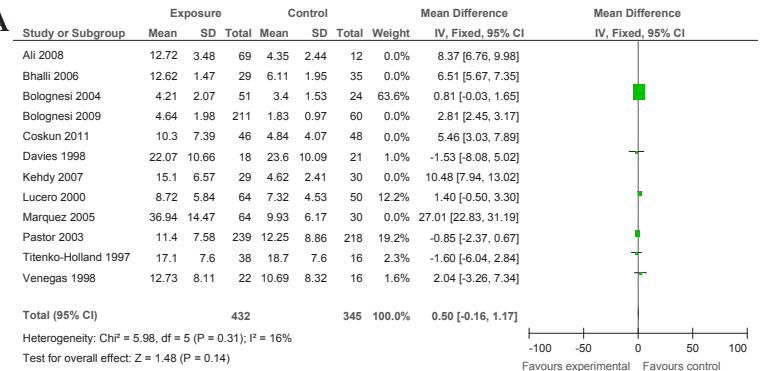

Figure 3. Results of Sensitivity Analyses

exposed group and control group among smokers and nonsmokers, male and female population, and American, Asian and European country in stratified analyses, and the summary estimates of weighted mean difference were 10.09 (95\% CI: 4.11-16.07) and 6.65 (95\% CI: 3.32-9.98), 2.73 (95\% CI: $1.29-4.17)$ and 4.76 (95\% CI: 2.94-6.57), and 5.89 (95\% CI: 2.86-8.92), 8.82 (95\% CI: 4.80-12.85) and 7.28 (95\% CI: 4.03-10.54), respectively (Table 2).

\section{Bias diagnosis}

Publication bias was assessed for MN (22 studies) and MNC (12 studies). The results for MN (Figure 2A) and $\mathrm{MNC}$ (Figure 2B) were a symmetric funnel plot. Our results from Egger's test and Begg's test showed that there was no publication bias for MN and MNC among total population as well (Table 2). Publication bias might not have significant influences on the summary estimates of $\mathrm{MN}$ in stratified analyses as well (Table 2).

\section{Sensitivity analyses}

We conducted the sensitivity analyses and found that the study including Bolognesi et al., 1993, Bolognesi et al., 2009, Coskun et al., 2011, Davies et al., 1998, Figgs et al., 2000, Lucero et al., 2000, Pasquini et al., 1996, TitenkoHolland et al., 1997, Tope et al., 2006 and Venegas et al., 1998 was homogenous for $\mathrm{MN}$, the $Q$ value for test of heterogeneity was $15.81(d f=9, p=0.07)$ and the summary estimate of weighted mean difference was 2.86 (95\% CI: 2.51-3.21) (Figure 3A). The study was homogenous for MNC, while including Bolognesi et al., 2004, Davies et al., 1998, Lucero et al., 2000, Pastor et al., 2003, TitenkoHolland et al., 1997 and Venegas et al., 1998, the $Q$ value for test of heterogeneity was $5.98(d f=5, p=0.31)$ and the summary estimate of weighted mean difference was 0.50 (95\% CI: -0.16-1.17) (Figure 3 B). 


\section{Discussion}

Micronuclei originate mainly from chromosome breaks or whole chromosomes that fail to engage with the mitotic spindle and therefore lag behind when cells divide. It is the only biomarker that permits the assessment of both clastogenic and aneugenic effects in a vast range of cells, since they are determined in interphase. CBMN assay in human peripheral blood lymphocytes was firstly established by Fenech in 1985, which had several advantages such as speed and ease of analysis, no requirement for metaphase cells and reliable identification of cells that have completed only one nuclear division, comparing with chromosomal aberrations and the conventional micronucleus (Fenech, 1997). Frequencies of $\mathrm{CBMN}$ in peripheral blood lymphocytes were the most frequent cytogenetic biomarkers of occupational population exposed to pesticides. Recently, El-zein has reported that CBMN assay might be a good predictor of lung cancer risk (El-Zein et al., 2006).

Several studies have shown that certain pesticide induced an increase frequency of $\mathrm{MN}$ and MNC in assays performed in vitro. Zeljezic et al found that the total number of micronuclei was significantly increased in cytokinesis-blocked lymphocytes treated with $0.4 \mu \mathrm{g} / \mathrm{ml}$ and $4 \mu \mathrm{g} / \mathrm{ml} 2$, 4-dichlorophenoxyacetic acid, compared to the negative controls (Zeljezic et al., 2004). A significant increase in micronucleated cells was found in isolated lymphocytes at high dose levels $(75-100 \mu \mathrm{g} / \mathrm{ml})$ of malathion in comparison with negative controls (TitenkoHolland et al., 1997). The total number of micronuclei observed in binuclear peripheral blood lymphocytes of the $p, p$ '-DTT-exposed samples (ranging from 32 to 47) was significantly greater than that detected in the unexposed control sample, where the total number of micronuclei was 7 (Garaj-Vrhovac et al., 2008). Surralles et al reported that significantly increased frequencies of micronuclei and micronucleated binucleated cells in cultured human lymphocytes were induced by a 48-hour treatment with alachlor, compared with negative controls (Surralles et al., 1995).

Our meta-analysis showed that the frequency of $\mathrm{MN}$ in peripheral blood lymphocytes was significantly higher in the pesticide-exposed group than that in control group evidenced by a random-effects model, where the summary estimate of weighted mean difference was 6.82 (95\% CI: 4.86-8.78). A significantly increased frequency of MNC in peripheral blood lymphocytes was also observed in the pesticide-exposed group compared with control group, the summary estimate of weighted mean difference was 5.08 (95\% CI: 2.93-7.23), but the summary estimate of weighted mean difference was 0.50 (95\% CI: -0.16$1.71)$ in sensitivity analysis. Our findings indicated that exposure to pesticides could induce significantly increased levels of chromosome damage in peripheral blood lymphocytes measured by MN, which might be a more sensitive indicator of early genetic effects than MNC by using CBMN assay for occupationally pesticide-exposed population.

There are some limitations inherent in this present meta-analysis. Firstly, only published literatures were included in this study. Therefore, publication bias may have occurred. To address this issue, both Egger's test and Begg's test were conducted simultaneously. Our results showed that the likelihood of key publication bias was negligible in this present study. Secondly, several factors such as sex, age, duration, smoking status, category of pesticide and levels of environmental exposure to pesticides might affect the frequency of $\mathrm{MN}$ in peripheral blood lymphocytes. Bolognesi et al observed an age-related increase of $\mathrm{MN}$ in human lymphocytes (Bolognesi et al., 1997); Bonassi et al reported that sex had an influence on MN evidenced from a large sample and review of the literature (Bonassi et al., 1995). Smoking status and sex were stratified in this meta-analysis for MN frequency further, and we also observed a significantly higher frequency of MN in peripheral blood lymphocytes among smokers and nonsmokers, male and female population exposed to pesticides in comparison with their corresponding control group, respectively. However, other confounders were not stratified in this meta-analysis, since only a few investigators reported such results and stratified range was not uniform for some factors. Thirdly, since both studies on MN and MNC were heterogeneous, we performed sensitivity analysis further, and found that the studies were homogenous for MN and MNC, when some articles were excluded.

Considering that the origin of studied population might have effects on the MN frequency among subjects exposed to pesticides, country of studied population was stratified in this meta-analysis further. We observed that there were significantly increased frequencies of $\mathrm{MN}$ in exposed group among American, Asian and European country, compared with their corresponding control group.

It is acknowledged that there is the main limitation of the classification of pesticides. Pesticides encompass many distinct chemicals and chemical classes including herbicides, insecticides, acaricides, rodenticides and fungicides. Some of them are used to kill weeds, while others kill insects and other pests via a variety of mechanisms of action. Perhaps, different pesticides had different cytogenetic effects on organisms. Stratification on category of pesticides should be performed in this meta-analysis. However, almost all of studies included in this study reported complex pesticides exposure rather than single pesticide exposure. Therefore, we could not perform sub-analysis on pesticides classification.

In summary, results from this current meta-analysis showed a significant increase in $\mathrm{MN}$ frequency in peripheral blood lymphocytes among pesticide-exposed population. $\mathrm{MN}$ might be a more sensitive biomarker than MNC while being used to evaluate the genetic damage induced by occupational exposure to pesticides. However, our meta-analysis was performed on population-based study, meta-analysis based on individual data might provide more precise and reliable results. When sufficient individual data are available, it may be likely to deal with the issue of confounders including sex, age, duration, smoking status, category of pesticides and levels of exposure to pesticides. 


\section{References}

Alavanja MC (2009). Introduction: pesticides use and exposure extensive worldwide. Rev Environ Health, 24, 303-9.

Alavanja MC, Samanic C, Dosemeci M, et al (2003). Use of agricultural pesticides and prostate cancer risk in the Agricultural Health Study cohort. Am J Epidemiol, 157, 800-14.

Andreotti G, Freeman LE, Hou L, et al (2009). Agricultural pesticide use and pancreatic cancer risk in the agricultural health study cohort. Int J Cancer, 124, 2495-500.

Balasubramaniam G, Saoba S, Sarade M, Pinjare S (2013). Casecontrol study of risk factors for Non-Hodgkin lymphoma in Mumbai, India. Asian Pac J Cancer Prev, 14, 775-80.

Begg CB, Mazumdar M (1994). Operating characteristics of a rank correlation test for publication bias. Biometrics, 50, 1088-101.

Bolognesi C, Abbondandolo A, Barale R, et al (1997). Agerelated increase of baseline frequencies of sister chromatid exchanges, chromosome aberrations, and micronuclei in human lymphocytes. Cancer Epidemiol Biomarkers Prev, 6, 249-56.

Bolognesi C, Carrasquilla G, Volpi S, Solomon KR, Marshall EJ (2009). Biomonitoring of genotoxic risk in agricultural workers from five colombian regions: association to occupational exposure to glyphosate. J Toxicol Environ Health A, 72, 986-97.

Bolognesi C, Creus A, Ostrosky-Wegman P, Marcos R (2011). Micronuclei and pesticide exposure. Mutagenesis, 26, 19-26.

Bolognesi C, Landini E, Perrone E, Roggieri P (2004). Cytogenetic biomonitoring of a floriculturist population in Italy: micronucleus analysis by fluorescence in situ hybridization (FISH) with an all-chromosome centromeric probe. Mutat Res, 557, 109-17.

Bolognesi C, Parrini M, Bonassi S, Ianello G, Salanitto A (1993). Cytogenetic analysis of a human population occupationally exposed to pesticides. Mutat Res, 285, 239-49.

Bonassi S, Bolognesi C, Abbondandolo A, et al (1995). Influence of sex on cytogenetic end points: evidence from a large human sample and review of the literature. Cancer Epidemiol Biomarkers Prev, 4, 671-9.

Coskun M, Cayir A, Ozdemir O (2011). Frequencies of micronuclei (MNi), nucleoplasmic bridges (NPBs), and nuclear buds (NBUDs) in farmers exposed to pesticides in Canakkale, Turkey. Environ Int, 37, 93-6.

Costa C, Teixeira JP, Silva S, et al (2006). Cytogenetic and molecular biomonitoring of a portuguese population exposed to pesticides. Mutagenesis, 21, 343-50.

Davies HW, Kennedy SM, Teschke K, Jenny P, Quintana E (1998). Cytogenetic analysis of South Asian berry pickers in British Columbia using the micronucleus assay in peripheral lymphocytes. Mutat Res, 416, 101-13.

DerSimonian R, Laird N (1986). Meta-analysis in clinical trials. Control Clin Trials, 7, 177-88.

Egger M, Davey Smith G, Schneider M, Minder C (1997). Bias in meta-analysis detected by a simple, graphical test. $B M J$, 315, 629-34.

El-Zein RA, Schabath MB, Etzel CJ, et al (2006). Cytokinesisblocked micronucleus assay as a novel biomarker for lung cancer risk. Cancer Res, 66, 6449-56.

Fenech M (1997). The advantages and disadvantages of the cytokinesis-block micronucleus method. Mutat Res, 392, 11-8.

Figgs LW, Holland NT, Rothmann N, et al (2000). Increased lymphocyte replicative index following 2 , 4-dichlorophenoxyacetic acid herbicide exposure. Cancer Causes Control, 11, 373-80.

Fritschi L, Benke G, Hughes AM, et al (2005). Occupational exposure to pesticides and risk of non-Hodgkin's lymphoma. Am J Epidemiol, 162, 849-57.

Garaj-Vrhovac V, Gajski G, Ravlic S (2008). Efficacy of HUMN criteria for scoring the micronucleus assay in human lymphocytes exposed to a low concentration of $p, p^{\prime}$-DDT. Braz J Med Biol Res, 41, 473-6.

Gilden RC, Huffling K, Sattler B (2010). Pesticides and health risks. J Obstet Gynecol Neonatal Nurs, 39, 103-10.

Hardell L, Eriksson M, Degerman A (1995). Metaanalysis of 4
Swedish case-control studies on exposure to pesticides as riskfactor for soft-tissue sarcoma including the relation to tumorlocalization and histopathological type. Int J Oncol, 6, 847-51.

Koutros S, Lynch CF, Ma X, et al (2009). Heterocyclic aromatic amine pesticide use and human cancer risk: results from the U.S. agricultural health study. Int J Cancer, 124, 1206-12.

Kumar A, Vashist M, Rathee R (2014). Maternal factors and risk of childhood leukemia. Asian Pac J Cancer Prev, 15, 781-4.

Lee WJ, Alavanja MC, Hoppin JA, et al (2007). Mortality among pesticide applicators exposed to chlorpyrifos in the agricultural health study. Environ Health Perspect, 115, 528-34.

Lee WJ, Blair A, Hoppin JA, et al (2004). Cancer incidence among pesticide applicators exposed to chlorpyrifos in the agricultural health study. J Natl Cancer Inst, 96, 1781-9.

Lucero L, Pastor S, Suarez S, et al (2000). Cytogenetic biomonitoring of Spanish greenhouse workers exposed to pesticides: micronuclei analysis in peripheral blood lymphocytes and buccal epithelial cells. Mutat Res, 464, 255-62.

Merhi M, Raynal H, Cahuzac E, et al (2007). Occupational exposure to pesticides and risk of hematopoietic cancers: meta-analysis of case-control studies. Cancer Causes Control, 18, 1209-26.

Orsi L, Delabre L, Monnereau A, et al (2009). Occupational exposure to pesticides and lymphoid neoplasms among men: results of a French case-control study. Occup Environ Med, 66, 291-8.

Pasquini R, Scassellati-Sforzolini G, Angeli G, et al (1996). Cytogenetic biomonitoring of pesticide-exposed farmers in central Italy. J Environ Pathol Toxicol Oncol, 15, 29-39.

Pastor S, Creus A, Parron T, et al (2003). Biomonitoring of four European populations occupationally exposed to pesticides: use of micronuclei as biomarkers. Mutagenesis, 18, 249-58.

Rajabli N, Naeimi-Tabeie M, Jahangirrad A, et al (2013). Epidemiology of leukemia and multiple myeloma in Golestan, Iran. Asian Pac J Cancer Prev, 14, 2333-6.

Rusiecki JA, Patel R, Koutros S, et al (2009). Cancer incidence among pesticide applicators exposed to permethrin in the agricultural health study. Environ Health Perspect, 117, 581-6.

Surralles J, Catalan J, Creus A, et al (1995). Micronuclei induced by alachlor, mitomycin-C and vinblastine in human lymphocytes: presence of centromeres and kinetochores and influence of staining technique. Mutagenesis, 10, 417-23.

Taioli E, Bonassi S (2002). Methodological issues in pooled analysis of biomarker studies. Mutat Res, 512, 85-92.

Titenko-Holland N, Windham G, Kolachana P, et al (1997). Genotoxicity of malathion in human lymphocytes assessed using the micronucleus assay in vitro and in vivo: a study of malathion-exposed workers. Mutat Res, 388, 85-95.

Tope A, Bebe FN, Panemangalore M (2006). Micronuclei frequency in lymphocytes and antioxidants in the blood of traditional limited-resource farm workers exposed to pesticides. J Environ Sci Health B, 41, 843-53.

Van Maele-Fabry G, Duhayon S, Lison D (2007). A systematic review of myeloid leukemias and occupational pesticide exposure. Cancer Causes Control, 18, 457-78.

Van Maele-Fabry G, Libotte V, Willems J, Lison D (2006). Review and meta-analysis of risk estimates for prostate cancer in pesticide manufacturing workers. Cancer Causes Control, 17, 353-73.

Venegas W, Zapata I, Carbonell E, Marcos R (1998). Micronuclei analysis in lymphocytes of pesticide sprayers from Concepcion, Chile. Teratog Carcinog Mutagen, 18, 123-9.

Weichenthal S, Moase C, Chan P (2010). A review of pesticide exposure and cancer incidence in the Agricultural Health Study cohort. Environ Health Perspect, 118, 1117-25.

Yildirim M, Karakilinc H, Yildiz M, et al (2013). Non-Hodgkin lymphoma and pesticide exposure in Turkey. Asian Pac J Cancer Prev, 14, 3461-3.

Zeljezic D, Garaj-Vrhovac V (2004). Chromosomal aberrations, micronuclei and nuclear buds induced in human lymphocytes by 2,4-dichlorophenoxyacetic acid pesticide formulation. Toxicology, 200, 39-47. 